\title{
Methodological potential of the teleological principle of purpose
}

\author{
Yu.N.Golubchikov \\ golubchikov@list.ru \\ Lomonosov Moscow State University, Faculty of Geography
}

\begin{abstract}
The cognitive capabilities of the teleological paradigm of purpose are discussed. An inquiring mind everywhere sees that inanimate matter serves for living, and that, in turn, serves for a man. However, such a concept as "purpose" turned out from the contemporary science, although for a long time it went along the path of becoming the doctrine of purpose determination, or nomogenesis. The history of the substitution of the main paradigm of science from purpose to chance is traced. The overcoming of the catastrophic representations of Cuvier by the provisions of actualism and evolutionism is considered. From the middle of the 19th century, public opinion began to strengthen that every new scientific achievement casts doubt on religious beliefs. Criticism of biblical history began with the events of the Great Flood, as the key one in the Bible. The negative attitude to catastrophism in the Soviet scientific literature and the importance of ideology in the methodology of science are considered. The anthropic principle predetermines a radical restructuring of the general scientific methodology. It finally comes closer to religious knowledge. The anthropic principle is teleological and contains that goal ("eidos-entelechia") in the structure of matter that impels it. In this light, the power of science is again seen not in confrontation with religion, but in harmonization with it.
\end{abstract}

Keywords: teleology, evolutionism, actualism, catastrophism, ideology, anthropic principle, global geological catastrophes.

\section{Introduction. Geology harmonized with teleology}

Until the middle of the nineteenth century the vast majority of scientists believed that science elevates the mind to understanding God. Their geological surveys merged with teleological ones. An outstanding geographer of the XIX century Karl Ritter wrote about the original purpose of the Earth by an invisible higher world for the dwelling of mankind [1]. In the outlines of the continents and oceans, great thinkers of the past tried to guess the meaning, purpose and language.

Almost all scientists of those times assigned a decisive role in shaping the face of the Earth to the catastrophic power of water. They were neptunists. The main event was described in the Bible as the event of the Flood. The biblical flood was associated with the origin of petrifactions. The most obvious flood evidence included granite boulders, widely scattered across the northern plains of Europe and North America. Since granites come to the surface in the area of the Baltic and Canadian crystalline shields, it was obvious that they were transported from there by mighty flood waters. They essentially reworked the face of the Earth. Under the influence of the ideas of Neptunism and catastrophism, stratigraphy has been formed.

The most prominent representative of catastrophism was the founder of comparative anatomy and paleontology, Baron Georges Leopold Cuvier. Having studied the fossils of organisms in the Paris Basin, he came to the conclusion that earlier life was immeasurably richer than modern. It was impoverished by great extinctions under the influence of terrible and gigantic disasters. In this regard, Cuvier was the first environmentalist-alarmist, the creator of the first likeness of the Red Book.

Cuvier counted six catastrophic extinctions. The latter was an event of the biblical flood. At such times, Cuvier believed, qualitatively different extraordinary forces acted, possibly carried out according to different laws. Modern processes of decay do not allow accumulate any fossils. Cuvier claimed [2].
Cuvier pointed out that everything that can be found in other places as fossilized organisms is freshly frozen in the Far North. He especially paid attention to the frozen carcasses of mammoths. Cuvier believed that if the mammoths did not freeze immediately after they have been killed, rot would have decomposed them. "The same process destroyed them and froze the country in which they lived. This incident happened suddenly, instantly, without any gradualness" [2, P.11].

In this regard, Cuvier can also be nominated as the founder of permafrost science. True, modern permafrost scientists do not consider him such. In contrast to Cuvier, they consider the formation of permafrost, the accumulation of underground ice deposits and the extinction of mammoths as three independent sluggish processes.

\section{The overthrow of catastrophism}

Only very few rejected the authenticity of the biblical account of the Flood. The London Geological Society provided strong support for these unusual views. In 1830, the 33-year-old member of the Geological Society, lawyer Charles Lyell, begins year after year to publish three thick volumes, it would seem, from a sphere very far from jurisprudence, entitled "Basic principles of geology, or an attempt to explain the ancient changes in the Earth by current processes".

With investigative thoroughness, Lyell measured the rate of accumulation of modern rainfall in calm conditions of stagnant water bodies. It amounted to millimeters or few centimeters per year. Then he divided the thicknesses of the strata of sedimentary rocks known to him at this speed and received huge, at that time, age of the strata. If $300 \mathrm{~m}$ accumulated by centimeter per year, then we get the age of the thickness of 30 thousand years.

With attorney's pathos, Lyell began to prove that all geological processes and phenomena in the past were the same as now. No giant catastrophe clouded them. Everything went slowly and gradually. "From ancient times to the present day, no other reasons have acted, other than those that are now acting, and their actions have always been manifested with the same energy that 
they are showing now" [cit. 3, p. 211]. This statement has entered into science under the name of the principle of actualism (from Latin actualis - "real", "real"), or uniformism (from English uniformity - "uniformity" and "immutability"). His motto is "the present is the key to the past." He gave a paradigmatic view not only to all Earth sciences, but to all science.

Lyell especially attacked upon the ideas of the Great Flood contained in the traditions of the peoples of the whole world. The formation of relief forms and sediments attributable to the flood since began to explain by the action of slowly advancing and retreating huge ice covers.

Criticism of biblical history was thus begun with the events of the Great Flood, as a key one in the Bible. And the sacred picture must also be restored with the restoration of the truth about this global hydrosphere catastrophe. Since then, the importance of water in shaping the appearance of the earth's land has been steadily narrowing, up to the recognition of its leading role only in the formation of valley and coastal complexes. Relief forms previously attributed to water activity began to be interpreted as glacial, aeolian, nivational, and denudational. If hydrosphere disasters are mentioned, they are associated with breakthroughs of glacial waters only.

The weak link in Lyell's constructions was the appearance of new species with the extinction of old ones. $\mathrm{He}$ explained them with mysterious and supernatural reasons.

Lyell was assisted by the 27-year-old Charles Darwin. Darwin linked the cause of the extinction of some species and the appearance of others not with catastrophic extinctions, but with the slow actions of the forces of natural selection. Darwin strongly supported Lyell's uniformitarian views and even published several articles substantiating the ancient glaciation of the British Isles and South America [4]. In turn, Lyell, in the process of developing Darwin's teachings on evolution, published the book "Geological Evidence of the Antiquity of A man".

The teachings of two Charles struck the scientific world amazingly quickly. Each researcher knows what incredible works it takes to gain credibility among colleagues. But here it happened all at once to a lawyer among geologists, and to a priest among biologists. How so?

As the priest Daniil Sysoev, who was killed in 2009, stated, "the topic of participation in the spread of evolutionary teachings of secret societies certainly needs further investigation" [5, p. 46].

V. I. Vernadsky wrote: "Geological sciences in the 19th century forced religion and philosophy to bow to the scientific fact and redo their constructions by the power of logic and vital applications"[6, p.236]. And they bowed. Even in Orthodoxy, an evolutionary heresy condemned by Konstantin Bufeev rooted [7]. Only "in science, ideology determines what is a fact and what is not" $[8$, p. 32].

The denial of catastrophism was not just a desire to present the history of the Earth from a new scientific point of view. The British historian of geological science,
Charles Gillispie [9], argues that the true goal was to create alternative biblical theories about the appearance of the Earth and a man. This opened up the possibility of questioning the entire Christian worldview, discrediting the structure of Christian states associated with it, and, ultimately, taking possession of their capital, estates, and demesnes. "This means killing all bad people, as much as there are very few good people," says the five-year-old girl from A. Platonov's novel "The Foundation Pit". Her wise words seem to be the key to understanding the entire world history of the 20th and 21 st centuries.

From the middle of the 19th century, public opinion began to strengthen that every new scientific achievement deny religious beliefs. The confrontation of religion and science began. Biblical beliefs and teleology have been eliminated from the new worldview [10].

The term "catastrophism" is still used with a negative connotation. The attitude towards him in the Soviet scientific literature was like something almost criminal. The Great Soviet Encyclopedia quoted F. Engels: "Cuvier's theory of earthly revolutions was revolutionary in words and reactionary in practice." The following was the verdict of I.V. Stalin from the work "Anarchism or Socialism?": "It is clear that there is nothing in common between the Cuvier cataclysms and the dialectical method of Marx" [11]. It is also clear that it would be unlikely that after such words there would be anyone willing to join the ranks of catastrophists. "For many decades in the USSR, the very existence of the Flood was seen as a fairy tale, almost as a kind of religious propaganda about the catastrophe, which, according to Soviet ideology and, accordingly (!) the science of that time, simply could not be" [12, p. 75].

This also happened because in the period attributed to the ice age, a man appeared. And such an event the evolutionary doctrine does not think without the slow and gradual adaptations of monkeys to changes in the natural environment, which forced the monkeys to turn to work.

But what if there were no great apes? It would turn out to be the closest relatives of a person, say, cats. It seems, and in that case apologists for evolutionism would argue that with the onset of the ice age, some humanoid cats caught mice themselves to sewed fur coats from their skins. Those that didn't sew went extinct, and those that sewed went out into the people.

Ultimately, everything about fundamental genesis lies in the realm of science fiction. No matter how deeply we study the morphology of the body, we cannot say anything about its conceiving. No matter how deeply we understand geomorphology, we cannot judge the origin of the Earth.

But depending on the interpretation of the deformations, we get a different picture of the Earth history. Or there was a glacier and then we came from Africa and descended from monkeys. Or there was no glacier, and then, perhaps, our ancestors themselves flourished once here.

\section{Replacing the purpose for chance.}

In accordance with the teleology of Plato, the essence of objects of living nature is determined by their 
intangible fundamental principle - the defined purpose or "eidos". It is as if they predetermine the present from the future, and all things of the visible world tend to become like them.

Aristotle agreed with Plato. Nature, he said, acts with a definite ultimate goal ("entelechy"). So, a seed or an egg already initially contains the beginning of life, aspiration. Aristotle also believed that history was developing. It also has a goal. Therefore, the present is like programmed by the future, and the past is programmed by the present. Therefore, the search for ultimate goals is the first and most important task of studying nature [13].

L.S. Berg brilliantly demonstrated that the science has long gone the way of becoming the doctrine of determining goals or nomogenesis (Greek. Nomos "law"). Therefore, Berg called his concept nomogenesis, contrasting it with Darwinian development based on a chance [14].

According to his concept, the evolution of living systems is guided by a certain "channel" for a specific purpose. "There is every reason to believe that nomogenesis will be recognized as postmodern. And then a transdisciplinary paradigm may arise, approaches to which from different points of view are presented not only and not so much by biologists as by scientists from other fields of science. For those who understand what area this branch of science is invading, this seems like a super task. However, without setting a super task, there is little hope for the prosperity of science," writes V.N. Nevsky [15].

Everywhere an inquiring mind sees that inanimate matter serves life, and it, in turn, serves a man. The introduction of the teleological principle into knowledge allows us to explain the gigantic volumes of facts. "And this is the most necessary thing in history, where no event is played out without a goal" [16].

Teleology is condemned by modern ideologists of science. At the same time, carefully disguised teleologism is the essence of all teachings on progressive development, for example, in Soviet ideology with the idea of building a bright communist future.

In the basis of modern science the fundamental dogma about chance was laid. This chance has no purpose and cannot have it. However, this chance predetermines evolutionary progress.

\section{Retrieval to anthropocosmism.}

Yet in the era of the dark Middle Ages, a man felt himself in the center of the universe. For his sake the stars revolved, the moon shone. For him the sun rises and sets. All cosmology was anthropocentric.

From this obscurantism by the middle of the $\mathrm{XX}$ century there was no trace left. If life had been removed from the modern textbook of physics (natural sciences), the textbook would not have changed. Moreover, there is no place for humanity in the modern textbook of physics. Science began to interpret the emergence of humanity as a result of very long, but absolutely blind processes, and in the universe itself it saw neither greatness, nor beauty, nor meaning, nor purpose. "Expanding the world to an extraordinary scale, a new scientific worldview simultaneously reduced a person with all his interests and achievements - reduced all phenomena of life to a position of insignificant details in space" [17, p. 247].

Intuitive ideas of the past began to come to life unexpectedly from the 1970s. Then it turned out that the most important laws of physics are defined by 9 fundamental constants, such as the gravitational constant or electron charge. By the end of the $1980 \mathrm{~s}$, on 30 such constants were already indicated, then 70 , and today there are 200 of them [18]. Each of these constants is limited by very narrow values, it looks random, not related to the others, it seemed that it could have different values. But each time it became clear that not only these constants, but also their relationships are critically important for the existence of our world. Not a man with the Earth is tuned to them, but they themselves are filigree tuned to a man on Earth [19].

Even a small mental change in one of the constants leads to a loss of stability of the entire Universe. It will become not some other, suitable, let us say, for another matter, but in principle it will lose its physical meaning. A proton is 1836 times heavier than an electron. If this ratio becomes a little different, in the 28th unit after the decimal point, either the electron will fall on the proton and the whole world will turn into a desert of hydrogen, or, on the contrary, the electron will break away from the proton and everything will turn into something even worse [19].

And if the slightest change in the numerical values of one of the constants of the Universe occurs, it will mean "the end of the world," that is, the entire material universe with all its countless galaxies.

Many attempts have been made to destroy the anthropic principle. It was about a multitude of universes, about the conventionality of the principle according to which the modality of obligations is not correct in science. But the anthropic principle itself is increasingly penetrating the sphere of general scientific (including humanitarian) culture $[20 ; 21 ; 22]$.

The idea of the Pythagoreans that "numbers rule the world" and create its order is again relevant. The Greek root "cosmos" itself means "order", and the word "cosmos" is translated as a universe arranged in strict order. Hence the "cosmetics". The order is directly opposite to chaos and can only turn into it, but not born from chaos. Beauty itself also serves as an attractor of any order, not excluding the cosmic. Awareness comes about fine tuning and earthly nature on human.

The anthropic principle is teleological. It is that goal ("eidos-entelechia") that is contained in the structure of matter and directs it. In modern systemic phraseology, such goals are called attractors (lat. Attrahere - to attract). E.N. Knyazev and S.P. Kurdyumov [23] convinces that it makes no sense to resist attractors. They make you move in the right direction. "If the system falls into the cone of attraction of the attractor, then there is a rigid set for a certain future state. The future draws to itself' [23, p. 145-146].

According to A.I.Subetto [24] with the anthropic principle, a peculiar nomogenesis of L.S. Berg is manifested in cosmogenesis, the cosmogonic regularity 
of the appearance of a man as an observer of the Universe, creating a new Cosmos - the technosphere. The anthropic principle not only allows the possibility of the appearance of a man, it determines its appearance. In the light of the anthropic principle, a man stands out not only as "the peak of the evolution of animal creatures", but also as the sacred one who orders the Cosmos. It became possible to exclaim: "Here is a man. What should be the universe ?! "

Alfred Wallace noted: "A man... could evolve here on Earth only with the presence of this whole monstrously vast material universe that we see around us" [25, p. 286]. K.E. Tsiolkovsky also regarded the whole cosmos as defining our life: "It is hard to imagine that any part of it will sooner or later have any effect on us" [26, p. 43]. It turns out that in order for such a small Earth to rotate around its axis in its orbit, the existence of a huge Universe with billions of trillions of stars is necessary. All of them are also important and necessary for us.

In religious language, the anthropic principle is called God's providence for a man. The most perspicacious minds guessed about the anthropic principle long before its appearance. K.E. Tsiolkovsky "ahead of the anthropic modern principles of cosmology, formed a more capacious anthropic principle. In his opinion, the evolution of space... necessarily leads to the appearance of Homo sapiens on Earth" [27, p. 76].

The idea of the connection of a man and the cosmos belongs to the oldest. V.P. Kaznacheev believed: "The salvation of mankind (preservation) ... consists in the search and discovery of the interaction of supporting connections with the forces of extra-planetary reason, cosmos-planet intelligence" [27, p. 155].

Science with the anthropic principle is again approaching religious knowledge, between which by the middle of the 20th century there was a practically insurmountable wall. It would seem that teleologism has long been overcome, but regains its fullness and orientation. Again, a certain plan of the universe and its creatures (nomogenesis) is revealed. But the plan also implies a goal.

\section{Anthropism of geological disasters}

What is the purpose of catastrophically fast burial places of the once booming life? Perhaps the formation of the universe was going a trial and error? But such a construction is directly opposite to the anthropic principle and approaches the evolutionary dogma of chance.

Let us try to understand these global catastrophes from the perspective of a goal, for which, of course, we will put forward a person. According to evolutionary views, the amount of living matter in the history of the planet should have increased from abiogenic Earth to the present day. But if we keep to the empirically observed facts, then the huge deposits of coal, oil and carbonates (limestone, chalk, dolomites, marls), that found in ancient earth strata, in particular, thick strata of carbonaceousgraphite schists, ferruginous quartzites, shungites and black schists of the early Archean, clearly indicate that the amount of living matter could only be reduced from that gigantic abundance to our time, as the great Cuvier wrote about it [6].

In the fossil record, it is sufficiently traced how each large extinction of organisms is preceded by large-scale growth of biodiversity and, obviously, biomass. Phytomass at this stage already absorbed more oxygen on the processes of decay than produced it. This process was apparently unstoppable. Stops of movement for life are equivalent to death and to prevent this from happening, life need inversions that stop the movement for a while, change the direction of the processes to the opposite, life need cyclicity [28].

The burial and isolation of such abundant biomass allowed new plants to re-saturate the atmosphere with oxygen. Coal, for example, consists of pure carbon, there is no oxygen in the coal, all the oxygen that could connect with the coal remained in the atmosphere. "If carbon had not dropped out of the life cycle in the form of hydrocarbons, coals, bitumen, graphites or in the form of calcium carbonates, free oxygen would not exist at all, there would also not be, therefore, thousands of the most important chemical reactions of the biosphere associated with it" [ 29, S. 248-249]. This buried organic matter is about 25 thousand times more than it is in the biosphere [30].

Now the accumulation of huge volumes of biomass is prevented by repeated fires from time to time. But they are possible only with a certain oxygen content in the atmosphere. Be it a few percent less, and any ignition processes will become impossible. All that remained was the quick burial path of the once booming life. They made it possible to saturate the planetary atmosphere with oxygen again.

In deposits of coal, hydrocarbons and carbonates, colossal reserves of carbon dioxide were also conserved. Without this conservation, the Earth could get at the fate of Venus. Giant burials of organic residues menacingly warn against violations of the fragile chemical composition of the earth's atmosphere.

Millions of invertebrates had to die and overflow with their fossils so that the Earth was covered with fertile soil. There is some lesson in all this. Man, "Man, "in order to cultivate the land from which he was taken" (Gen. 3: 23), " required many processes and revolutions that took place on the Earth... You do not walk on the floor of your house, poor man, but you walk on the roof of your house, and only a lot of floods gave your house its present appearance"- Johann Herder wisely taught [1977, p. 39]

\section{Conclusion. On the harmonization of science and religion.}

The modern confrontation between science and religion began with the substitution of the target for the dogma of chance. This randomness is the heart of modern scientific ideology and predetermines the natural evolutionary progress.

More than 50-70 years ago, nothing was known either about the fine-tuning of the Universe to human, or about the incredible complexity of the cell. It was entirely possible to allow spontaneous and random formation of 
such structures. The universe could be explained by evolution and actualism.

The incredible complexity of the world that has opened up brings religion and science together. Man now seeks God through physics and metaphysics. Man and the Universe, religion and science, are combined with the anthropic principle in a single holistic worldview. One can expect an expansion of the front of this contact. Having arisen in physics, the anthropic principle penetrates the sphere of general scientific (including humanitarian) culture. The power of science again appears not in confrontation with religion, but in harmonization with it.

\section{References:}

[1] Ritter K. General geography. - M: Edition of the book seller A.I. Glazunov, 1864. - 188 p.

[2] Cuvier J. Discours sur les révolutions de la surface $\mathrm{du}$ globe et sur les changements qu'elles ont produits dans le règne animal. - Odessa, 1840. - $225 \mathrm{p}$.

[3] Kuznetsov V.G. The value of the work of Charles Lyell in the formation of scientific ideology in geology // Lithology and Minerals, 2011, No. 2, - P. 209-222.

[4] Shatsky N.S., Yanshin A.L. Portraits of geologists. M.: Nauka, 1986.- 304 p.

[5] Sysoev D. Evolutionism in the light of Orthodox teachings // Six Day Against Evolution. - M.: Pilgrim, 2000, p. 41-64.

[6] Vernadsky V.I. Space and time in unalive and living nature // Philosophical thoughts of a naturalist. - M.: Nauka, 1988, p. 210-385.

[7] Bufeev K. Orthodox doctrine of the Creation. Volume 3. Orthodox doctrine of Creation and modern theology. - M.: Russian Publishing House. center them. St. Basil the Great, 2019. - 656 p.

[8] Gorkin A.P. On the relativism of economic geography (objective and subjective aspects) // Theory of socio-economic geography: current status and development prospects / Materials of the International Scientific Conference (Rostov-on-Don, May 4-8, 2010). - Rostov-on-Don, 2010, p.32-36.

[9] Gillispie, C.C. Genesis and Geology. The Impact of Scientific Discoveries upon Religious Beliefs in the Decades before Darvin - New York, Haprer Torchibooks, 1959. - 306 p.

[10] Jones R.H. For the Glory of God: The Role of Christianity in the Rise and Development of Modern Science. Vol II. The History of Christian Ideas and Control Beliefs in Science. - University press of America. 2012. - 272 p.

[11] Catastrophe theory (catastrophism) // Great Soviet Encyclopedia. - M.: BSE, 1953, p. 365-366.

[12] Grigoriev Al.A. The world of geography in the mirror of art. - SPb.: Asterion, 2019. - 238 p.

[13] Bremer J, Khroutski K, Klimek R, Tadeusiewicz R., Challenging integralism, Aristotelian Entelecheia, Hyle and Morphe (Form), and Contemporary Concepts of Information, Touching upon the Aetiological Issues of Carcinogenesi //
Biocosmology-Neo-Aristotelism Vol. 7, No. 1 (Winter 2017). - $111 \mathrm{p}$.

[14] Berg L.S. Proceedings on the theory of evolution. M.: Nauka, 1977. - 388 p.

[15] Nevsky V.N. Geomorphology and postmodern // Scientific dialogue, 2015, No. 2 (38), p. 6-20.

[16] Gogol N.V. Articles. / Selected Works. Vol. VI - M.: Fiction, 1986. - 544 p.

[17] Vernadsky V.I. Problems of biogeochemistry // Transactions of the Biogeochemical laboratory. T. XVI. - M.: Nauka, 1980. - 320 p.

[18] Lanza R., Berman B. Biocentrism. How life creates the universe. - St. Petersburg: Peter, 2015. - 224 p.

[19] Lewis G.F. and Barnes L.A., A Fortunate Universe: Life in a Finely Tuned Cosmos. - Cambridge: Cambridge University Press, 2016. - 373 p.

[20] Armand A.D. Gaia experiment. The problem of the living earth. - M.: Sirin Sadhana, 2001. - 192 p.

[21] Topchiev A.G., Yavorskaya V.V. Methodological issue sand transformation in contemporary socioeconomic geography // Geographic digest, 2011, 1, p.11-16.

[22] Barnes L.A., and Lewis G.F. The Cosmic Revolutionary Handbook: (Or: How to Beat the Big Bang). - Cambridge: Cambridge University Press, 2020. - 286 p

[23] Knyazeva E.N., Kurdyumov S.P. The bases of synergetics: synergetic worldview. - M.: Kom Book, 2005. - 240 p.

[24] Subetto A.I. Pantacreator's ideas in modern science // Systemogenetics and the doctrine of cyclical development. Book 1. Tolyatti: MABiBD, 1994, p. 217-220.

[25] Wallace A. R. The place of man in the Universe. SPb., 1904. -292 p.

[26] Tsiolkovsky K.E. The reason for space, Essays on the Universe. - Kaluga: Golden Alley, 2001. - 384 p.

[27] Kaznacheev V.P. Questions of a new cosmogony: Digest of articles. - Novosibirsk: NGONB, 2013. $208 \mathrm{p}$.

[28] Mertsalov I.M. Fateful laws of the development of life and the attitude of scientists and " nonscientist " to them // System "Planets Earth". - M.: LENAND, 2020? p. 291-300.

[29] Vernadsky V.I. Essays on geochemistry. - M.: Nauka, 1983. - 424 p.

[30] Shaporenko S.I. The hydrosphere bilayer hypothesis: Justification and main results of the new concept // Geography Issues. Digest.133: Geographic and hydrological studies. - M.: Codex Publishing House, 2012, p. 117-139.

[31] Herder I.G. Ideas for the philosophy of the history of mankind. - M.: Nauka, 1977. - 704 p.

\section{About the author}

Golubchikov Yuri N., Ph.D., Leading Researcher, Department of Recreational Geography and Tourism, Lomonosov Moscow State University. E-mail: golubchikov@list.ru. 